\title{
PELATIHAN PEMBUATAN HAND SANITIZER KEPADA PEKERJA DAN NASABAH BANK SAMPAH ROSELA DI KELURAHAN PANGKALAN JATI BARU, DEPOK
}

\author{
Noor Hidayati ${ }^{1}$, Isnanda Nuriskasari ${ }^{1}$, Rahmat Subarkah ${ }^{1}$ \\ ${ }^{1}$ Politeknik Negeri Jakarta \\ noor.hidayati@mesin.pnj.ac.id ${ }^{1}$, isnanda.nuriskasari@mesin.pnj.ac.id ${ }^{1}$, \\ rahmat.subarkah@mesin.pnj.ac.id ${ }^{1}$
}

Submitted: 12 Agustus 2020 Accepted:18 April 2021 Published: 30 April 2021

\begin{abstract}
Abstrak
Hand sanitizer merupakan cairan atau gel beralkohol yang dapat digunakan untuk mengurangi patogen pada tangan. Penggunaan hand sanitizer dilakukan saat akses terhadap sabun dan air sulit terjangkau. Pentingnya penggunaan hand sanitizer dirasakan saat sedang berpergian maupun berkerja. Masalah yang timbul bila tidak menjaga kebersihan tangan dimasa pandemi COVID-19 yaitu dapat meningkatkan terkena pantogen yang dapat menurunkan stamina tubuh sehingga mudah terserang penyakit. Peran hand sanitizer sangat penting, namun sempat terjadinya kelangkaan akan hand sanitizer, untuk mencegah terjadinya hal serupa maka diperlukan pelatihan pembuatan dan pembagian hand sanitizer kepada nasabah dan pekerja bank sampah yang lebih rawan terkena penyakit yang terbawa oleh tangan. Untuk mengetahui efektifitas pelatihan maka dilakukan survei dan wawancara terhadap peserta pelatihan, berdasarkan hasil survei sebelum dan sesudah, terhadap peserta didapatkan antusiasme yang tinggi dan transfer knowledge yang baik, ditandai dengan keberhasilan pembuatan hand sanitizer oleh peserta, nilai survei yang tinggi sesudah pelatihan dan tingginya perminatan pelatihan serupa untuk produk kebersihan lainnya.

Kata Kunci: bank sampah, hand sanitizer, pelatihan, survei
\end{abstract}


HUMANISM Vol.2 No.1 April 2021

\section{PENDAhUluan}

Banyak penyakit menular contohnya seperti penyakit pernapasan yang disebabkan oleh virus corona yang menular melalui cairan tubuh (batuk, maupun bersin) dan melalui kontak tangan serta benda yang telah terpapar oleh virus tersebut. Hal ini menyebabkan virus korona sangat mudah menyebar. Bagi sebagian masyarakat yang sudah menyadari bahaya penyebaran dan tertularnya virus korona, mereka menjaga diri mereka dengan menjauhi keramaian, mengisolasi diri hingga menjaga kebersihan diri dengan cara mencuci tangan dengan sabun atau jika tidak ditemukan air, maka dapat membersihkan tangan dengan hand sanitizer.

Selain itu, selama ini telah berjalan upaya masyarakat untuk melakukan pola hidup bersih dan sehat dengan cara membentuk komunitas bank sampah. Di tengah merebaknya penyebaran virus korona, tentunya kinerja komunitas ini menjadi sedikit terganggu. Dalam hal ini kami melihat komunitas bank sampah "Rosela" yang berlokasi di Kelurahan Pangkalan Jati Baru, Kecamatan Cinere, Kota Depok. Anggota komunitas bank sampah Rosela terdiri kurang lebih 40 nasabah yang merupakan warga RW 01, Kelurahan Pangkalan Jati Baru, Depok.

Dalam rangka menjaga keberlangsungan pola hidup bersih dan sehat di masyarakat dalam bentuk komunitas bank sampah dan juga mencegah penyebaran virus corona semakin luas, kami atas nama tim dosen Jurusan Teknik Mesin Politeknik Negeri Jakarta melakukan salah satu kegiatan tridharma perguruan tinggi yaitu Pengabdian Kepada Masyarakat kepada Pekerja Pengelola dan Nasabah Bank
Sampah Rosela di Kelurahan Pangkalan Jati Baru, Cinere, Depok. Berdasarkan hasil diskusi dengan penanggung jawab pengelola bank sampah, bahwa memang benar terdapat kekhawatiran tersendiri bagi para pekerja dalam melaksanakan tugas. Hal ini dikarenakan semakin ramainya berita penyebaran penyakit mematikan seperti virus korona yang dapat dengan mudah menular. Para pekerja menjadi rentan terhadap berbagai penyakit menular salah satunya virus corona. Sedangkan saat ini terjadi kelangkaan hand sanitizer yang sangat berguna untuk membersihkan tangan di saat sedang berkerja atau dalam kondisi darurat jauh dari akses air dan sabun.

Berdasarkan hasil diskusi dan survei ke lokasi tersebut, tim Dosen Jurusan Teknik Mesin Politeknik Negeri Jakarta berinisiatif untuk melakukan pelatihan pembuatan hand sanitizer dan pembagian hand sanitizer kepada para pekerja, dan nasabah bank sampah dengan harapan dapat menjaga kinerja bank sampah dan meningkatkan kualitas kesehatan pengelola dan nasabah bank sampah yang telah berjasa atas kebersihan masyarakat dilingkungan sekitar.

Tujuan kegiatan pengabdian pada masyarakat Kelompok Dosen Jurusan Teknik Mesin adalah untuk menjaga kinerja bank sampah dan meningkatkan kualitas kesehatan pekerja pengelola dan nasabah bank sampah melalui program penyuluhan kesehatan, pelatihan pembuatan dan pembagian gratis hand sanitizer kepada pekerja pengelola dan nasabah bank sampah "Rosela" di kelurahan Pangkalan Jati Baru, yang dilakukan pada tahun 2020. 


\section{TINJAUAN PUSTAKA}

Kebersihan tangan merupakan hal penting dalam mencegah penyakit menular, tangan yang kotor menjadi tempat berkumpulnya kuman penyakit. Oleh karena itu perlu adanya edukasi tentang kebersihan tangan, karena dengan edukasi kebersihan tangan dapat meningkatkan kepedulian terhadap kebersihan tangan (Kahusadi et al., 2018). Kebersihan tangan dapat dilakukan melalui mencuci tangan dengan air dan sabun, namun apabila sedang berpergian maupun berkerja, dimana akses air dan sabun sulit dijangkau kebersihan tangan tetap dapat terjamin melalui penggunaan hand sanitizer. Keefektifan hand sanitizer dalam membunuh kuman pembawa penyakit telah banyak diteliti oleh para ilmuan (Desiyanto \& Djannah, 2013; Golin et al., 2020; Situmeang \& Sembiring, 2019; Srikartika et al., 2016)

Tata cara pembuatan handsanitizer telah banyak beredar luas (Olsen, 2020), namun pada pelatihan kali ini, pembuatan hand sanitizer dibuat berdasarkan surat edaran Badan POM Nomor KP.11.01.2.83.03.20.14 tentang "Pembuatan Handsanitizer dalam Upaya Mencegah Virus Corona" yang dibuat sesuai standar WHO. Mengutip langsung tata cara pembuatan berdasarkan berdasarkan surat edaran Badan POM yang merujuk pada standar WHO adalah sebagai berikut:

Bahan-bahan

1. Gliserol $98 \%$

2. Ethanol $96 \%$

3. Hidrogen Peroksida 3\%

4. Aquadest atau air steril

Alat

1. Gelas ukur $1000 \mathrm{~mL}$

2. Becker glass
3. Gelas ukur $50 \mathrm{~mL}$

4. Gelas ukur $25 \mathrm{~mL}$

5. Batang pengaduk

6. Botol kaca

Prosedur

1. Sejumlah $833 \mathrm{~mL}$ ethanol $96 \%$ dimasukan kedalam Gelas ukur 1000 mL

2. Tambahkan 41,7 mL Hidrogen Peroksida $3 \%$ kedalam gelas ukut berisi ethanol

3. Selanjutnya tambahkan $14,5 \mathrm{~mL}$ Gliserol 98\% menggunakan gelas ukur, dan pastikan tidak ada sisa gliserol didalam gelas ukur, dengan cara membilas menggunakan aquades atau air steril

4. Tambahkan aquades atau air steril hingga volume campuran mencapai $1000 \mathrm{~mL}$, aduk hingga homogen

5. Pindahkan kedalam botol kaca bersih

6. Simpan selama 72 jam untuk memastikan tidak adanya kotaminasi organisme dari wadah botol

\section{Hand sanitizer siap digunakan}

\section{METODE PENELITIAN}

Pada pelatihan pembuatan hand sanitizer kepada pekerja dan nasabah bank sampah rosela di kelurahan Pangkalan Jati Baru, Depok. Penelitian dilakukan untuk melihat keefektifan pelatihan yang telah diberikan, melalui survey sebelum dan sesudah pelatihan. Peserta diberikan pertanyaan yang sama pada saat sebelum pelatihan dimulai dan setelah pelatihan selesai. Peserta terdiri dari pekerja dan nasabah bank sampah dengan jumlah 35 orang yang terbagi dalam dua kelas. Tujuan pembagian peserta dalam dua kelas adalah untuk mencegah terjadinya penularan Virus Covid-19. Selama pelatihan baik peserta 
HUMANISM Vol.2 No. 1 April 2021

maupun panitia menerapkan social distance dan pemakaian masker. Adapun variabel dalam penelitian yang tertuang survey sebelum dan sesudah dijelaskan pada Tabel 1.

Kolom pertama pada table di atas menunjukan variabel yang akan disurvei, yaitu variable pengetahuan dan ketertarikan. Ruang lingkup yang akan diteliti dalam variable pengetahuan meliputi pengetahuan akan manfaat, proses pembuatan, dan produk hand sanitizer. Isi dari kolom indikator merupakan pertanyaan yang akan ditanyakan pada saat survei. Pertanyaan yang digunakan dalam variable pengetahuan ialah kedalaman pengetahuan akan manfaat hand sanitizer, kedalaman pengetahuan akan proses pembuatan hand sanitizer, dan kedalaman pengetahuan akan produk hand sanitizer. Skala Likert digunakan dalam mengukur kedalaman pada variable pengetahuan.

Ruang lingkup yang akan diteliti dalam variable

Ruang lingkup yang akan diteliti dalam variable ketertarikan adalah kepeduliah terhadap kebersihan tangan, dan ketertarikan terhadap produk hand sanitizer. Adapun pertanyaan yang akan ditanyakan meliputi. Seberapa dalam kepedulian peserta terhadap kebersihan tangan dan seberapa dalam ketertarikan peserta terhadap produk hand sanitizer. Skala Likert digunakan dalam mengukur variable ketertarikan.

Tabel 1. Variable Penelitian

\begin{tabular}{|c|c|c|c|}
\hline Variabel & Ruang Lingkup & Indikator & Skala \\
\hline \multirow[t]{4}{*}{ Pengetahuan } & $\begin{array}{l}\text { Pengetahuan peserta } \\
\text { dalam manfaat hand } \\
\text { sanitizer,proses } \\
\text { pembuatan,dan produk } \\
\text { hand sanitizer }\end{array}$ & & Likert (1-5) \\
\hline & & $\begin{array}{l}\text { pengetahuan tentang } \\
\text { manfaat hand sanitizer }\end{array}$ & \\
\hline & & $\begin{array}{l}\text { pengetahuan tentang } \\
\text { pembuatan hand } \\
\text { sanitizer }\end{array}$ & \\
\hline & & $\begin{array}{l}\text { pengetahuan tentang } \\
\text { produk hand sanitizer }\end{array}$ & \\
\hline \multirow[t]{2}{*}{ Ketertarikan } & $\begin{array}{l}\text { Kebersihan tangan } \\
\text { dalam mencegah } \\
\text { penyakit, ketertarikan } \\
\text { dalam penggunaan dan } \\
\text { info mengenai hand } \\
\text { sanitizer }\end{array}$ & $\begin{array}{l}\text { kepedulian terhadap } \\
\text { kebersihan tangan }\end{array}$ & Likert (1-5) \\
\hline & & $\begin{array}{l}\text { ketertarikan dengan } \\
\text { produk hand sanitizer }\end{array}$ & \\
\hline
\end{tabular}




\subsection{Analisis Data}

Dalam menilai hasil survey, metode analisis data yang digunakan menggunakan skala Likert (Aprilia \& Ghozali, 2013) dengan skor tertinggi di tiap pertanyaannya adalah 5 dan skor terendah adalah 1.metode analisis dengan likert telah banyak digunakan dalam menganalisis hasil survey (Mukti et al., 2017; Sullivan \& Artino, 2013; Suwandi et al., 2018). Oleh karena itu, pada penelitian kali ini analisis data survey dilakukan menggunakan skala likert. Survei dilakukan dengan jumlah responden sebanyak 35 orang. Dalam menganalisis hasil kuisioner, diperlukan beberapa tahap perhitungan. Tahap pertama adalah menjumlahkan nilai hasil responden dengan rumus : $\mathbf{T} \mathbf{X} \mathbf{P n}$

$\mathrm{T}=$ Jumlah responden yang memilih

$\mathrm{Pn}=$ Pilihan angka skor Likert

Penilaian ini dilakukan disemua kolom pertanyaa, salah satu contoh perhitungan dilakukan pada kolom pertanyaan " seberapa dalam pengetahuan anda terhadap manfaat hand sanitizer"

Responden yang menjawab sangat baik

(5) $=20 \times 5=100$

Responden yang menjawab baik

(4) $=6 \times 4=24$

Responden yang menjawab netral

(3) $=2 \times 3=6$

Responden yang menjawab buruk

(2) $=2 \times 2=4$

Responden yang menjawab sangat buruk

(1) $=5 \times 1=5$

Total nilai 139

\section{Langkah berikutnya adalah} menginterpretasikan total nilai, dengan cara mengetahui terlebih dahulu skor tertinggi dalam item penilaian dengan rumus berikut

Skor tertinggi $(Y)=$ skor tertinggi likert $\mathrm{x}$ jumlah responden

Skor tertinggi $(\mathrm{Y})=5 \times 35$

Skor tertinggi $(\mathrm{Y})=175$

Dari nilai $Y$ akan didapatkan interpretasi kuestioner menggunakan rumus index \% sebagai berikut :

Index $\%=$ Total nilai $/$ Y x 100\%

Index $\%=139 / 175 \times 100 \%$

Index $\%=79,43 \%$

Sehingga dengan total nilai 139 memiliki indeks $\%$ sebesar 79,43\%.

Dimana, nilai tersebut termasuk nilai dengan definisi Baik berdasarkan nilai interval.

Nilai interval dapat dihitung dengan rumusan sebagai berikut:

$\mathrm{I}=100$ /jumlah skor likert

$\mathrm{I}=100 / 5$

$\mathrm{I}=20$

20 merupakan interval jarak dari nilai terendah $0 \%$ hingga nilai tertinggi $100 \%$ sehingga didapatkan nilai interval sebagai berikut:

Angka 0\% - 19,99\% = Sangat (tidak setuju/ buruk/kurang sekali)

Angka 20\% - 39,99\% = Tidak setuju / Kurang baik)

Angka 40\% - 59,99\% = Cukup / Netral

Angka 60\% - 79,99\% = $($ Setuju/Baik/suka $)$

Angka 80\% - 100\% = Sangat $($ setuju/Baik/Suka)

\subsection{Interview}

Interview atau tanya jawab dilakukan secara komunal disaat pelatihan sudah selesai, dan adapula pertanyaan yang dituliskan bersamaan dengan survey pada akhir pelatihan. Adapun pertanyaan yang ditanyakan perihal kendala 
selama pelatihan, keinginan untuk membuat hand sanitizer setelah selesai pelatihan, saran kedepan untuk panitia, jenis pelatihan yang diharapan kedepannya

\section{HASIL DAN PEMBAHASAN}

\subsection{Hasil Survei}

Berdasarkan hasil perhitungan analisis data, didapatkan nilai pada tabel 2 .

Survei dibagikan sebelum pelatihan dimulai dan sesudah pelatihan selesai. Tabel 2 menunjukan hasil rekapitulasi nilai survei sebelum dan sesudah pelatihan (beforeafter). Berdasarkan hasil penilaian didapatkan bahwa sebelum dilaksankannya pelatihan, para peserta memiliki pengetahuan yang baik mengenai manfaat hand sanitizer ditunjukan dengan nilai score sebesar 79,43\%. Namun, para peserta diketahui memiliki kekurangan dalam pengetahuan terkait pembuatan hand sanitizer, hal ini dapat dilihat dari nilai sebelum pelatihan yang hanya sebesar $31,43 \%$.

Setelah pelatihan, diketahui peserta memiliki lebih banyak pengetahuan tentang manfaat dan pembuatan hand sanitizer. Hal ini terlihat dari naiknya nilai pengetahuan manfaat hand sanitizer menjadi $97,14 \%$ dari yang sebelumnya hanya $79,43 \%$. Setelah pelatihan, pada variabel pengetahuan mengenai pembuatan hand sanitizer diketahui naik secara significant dari yang sebelumnya bernilai kurang yaitu hanya sebesar 31,43\% menjadi 92\%, yang berarti bahwa para peserta setelah mengikuti pelatihan memiliki pengetahuan yang sangat baik terkait pembuatan hand sanitizer. Hal serupa terjadi pula pada pengetahuan mengenai produk hand sanitizer, sebelum pelatihan para peserta diketahui memiliki pengetahuan yang cukup terhadap produk hand sanitizer, setelah pelatihan peserta memiliki pengetahuan yang sangat baik terhadap produk hand sanitizer. Hal ini ditandai dengan naiknya nilai dari 45,14\% menjadi 98,29\%

Adapun pada variabel ketertarikan dan kepedulian. Pada awal pelatihan peserta sudah memiliki kepedulian yang sangat tinggi terhadap kebersihan tangan, maupun ketertarikan terhadap produk hand sanitizer. Dengan adanya pelatihan hand sanitizer ini memperkuat kepedulian peserta terhadap kebersihan tangan dan ketertarikan terhadap produk hand sanitizer. Hal ini dapat dilihat dari Tabel 1 dengan nilai sebelum pelatihan terletak pada skor 98,86\% untuk kepedulian terhadap kebersihan tangan dan 90,86\% terhadap ketertarikan pada produk hand sanitizer, dan nilai setelah pelatihan naik menjadi 99,43\% terhadap kepedulian akan kebersihan tangan, dan 98,86\% terhadap ketertarikan pada produk hand sanitizer

\subsection{Hasil Interview}

Berdasarkan hasil interview maupun pertanyaan singkat diketahui bahwa kendala umum yang dialami oleh peserta adalah pada saat pengukuran cairan melalui gelas ukur, namun hal tersebut tidak menyurutkan antusiasme peserta dalam mempelajari pembuatan hand sanitizer, hal ini dapat dilihat bahwa 92\% peserta berkeinginan untuk membuat hand sanitizer sendiri, dan berharap ke depan terdapat pelatihan serupa. 
Tabel 2. Hasil Rekapitulasi Survey

\begin{tabular}{|c|c|c|c|}
\hline NO & PERNYATAAN & $\begin{array}{c}\text { SCORE } \\
\text { (BEFORE) }\end{array}$ & $\begin{array}{l}\text { SCORE } \\
(\text { AFTER) }\end{array}$ \\
\hline & pengetahuan & & \\
\hline 1 & $\begin{array}{l}\text { pengetahuan tentang manfaat hand } \\
\text { sanitizer }\end{array}$ & $79,43 \%$ & $97,14 \%$ \\
\hline 2 & $\begin{array}{l}\text { pengetahuan tentang pembuatan hand } \\
\text { sanitizer }\end{array}$ & $31,43 \%$ & $92 \%$ \\
\hline \multirow[t]{2}{*}{3} & pengetahuan tentang produk hand sanitizer & $45,14 \%$ & $98,29 \%$ \\
\hline & ketertarikan & & \\
\hline 4 & kepedulian terhadap kebersihan tangan & $98,86 \%$ & $99,43 \%$ \\
\hline 5 & ketertarikan dengan produk hand sanitizer & $90,86 \%$ & $98,86 \%$ \\
\hline
\end{tabular}

\section{KESIMPULAN}

Dengan adanya pelatihan dan pembagian hand sanitizer kepada para pekerja dan nasabah Bank Sampah Rosela di Kelurahan Pangkalan Jati Baru, Depok dapat secara nyata meningkatkan pengetahuan mengani manfaat, produk,dan pembuatan hand sanitizer serta kepedulian terhadap kebersihan tangan. Hal ini ditandai dengan tingginya nilai pengetahuan, keberhasilan membuat hand sanitizer, dan ketertarikan setelah pelatihan serta tingginya peminatan untuk mengadakan pelatihan serupa

\section{UCAPAN TERIMAKASIH}

Ucapan terima kasih ditujukan kepada UP2M PNJ yang telah membiayai program pengabdian kepada masyarakat kali ini sehingga program ini dapat terlaksana dengan baik. Tidak lupa penulis ucapkan terima kasih kepada mitra kami yaitu pengelola dan para nasabah Bank Sampah Rosela di kelurahan Pangkalan Jati Baru, Depok atas kesempatan yang diberikan.

\section{DAFTAR PUSTAKA}

Aprilia \& Ghozali, (2013). Teknik Penyusunan Skala Likert (Summated Scales) dalam

penelitian akuntansi dan bisnis. ISBN 978-60214650-1-1.

Desiyanto, F. A., \& Djannah, S. N. (2013). Efektivitas Mencuci Tangan Menggunakan Cairan Pembersih Tangan Antiseptik (Hand Sanitizer) Terhadap Jumlah Angka Kuman. Jurnal Kesehatan Masyarakat (Journal of Public Health), 7(2), 75-82. https://doi. org/10.12928/kesmas.v7i2.1041

Golin, A. P., Choi, D., \& Ghahary, A. (2020). Hand sanitizers: A review of ingredients, mechanisms of action, modes of delivery, and efficacy against coronaviruses. American Journal of Infection Control, June. $\quad$ https://doi.org/10.1016/j. ajic.2020.06.182

Kahusadi, O. A., Tumurang, M. N., \& Punuh, M. I. (2018). Pengaruh penyuluhan kebersihan tangan terhadap perilaku siswa SD GMIM 76 maliambao kabupaten minahasa utara. Jurnal Kesmas, 7(5), 1-9.

Mukti, G. W., Rasmikayati, E., Kusumo, R. A. B., \& Fatimah, S. (2017). PENINGKATAN NILAI TAMBAH LIMBAH KULIT MANGGA MELALUI PELATIHAN 
HUMANISM Vol.2 No. 1 April 2021

PEMBUATAN KERIPIKDANMANISAN

KULIT MANGGA. Jurnal Pengabdian

Kepada Masyarakat.

Situmeang, S. M. ., \& Sembiring, T. J. (2019). EFEKTIVITAS HAND SANITIZER DALAM MEMBUNUH KUMAN DI TANGAN. Jurnal Anatomi Laboratorium Medis. $\quad$ https://doi.org/10.1016/j. surfcoat.2019.125084

Srikartika, P., Suharti, N., \& Anas, E. (2016). Kemampuan Daya Hambat Bahan Aktif Beberapa Merek Dagang Hand sanitizer terhadap Pertumbuhan Staphylococcus aureus. Jurnal Kesehatan Andalas, 5(3), 540-545. https://doi.org/10.25077/jka. v5i3.613
Sullivan, G. M., \& Artino, A. R. (2013). Analyzing and Interpreting Data From Likert-Type Scales. Journal of Graduate Medical Education, 5(4), 541-542. https:// doi.org/10.4300/jgme-5-4-18

Suwandi, E., Imansyah, F. H., \& Dasril, H. (2018). Analisis Tingkat Kepuasan Menggunakan Skala Likertpada Layanan Speedy Yang Bermigrasi Ke Indihome. Jurnal Teknik Elektro.

Olsen, Sarah. (2020). How To Make Hand Sanitizer, Face Masks, \& Soap at Home in 2020. ISBN-13 : 979-8630725387. 